Research Article

\title{
Assessment of Riparian Vegetation Pattern along Alista Hilly River Basin
}

\author{
Rita Parmawati ${ }^{1 *}$, Lutvita Erya Rokani ${ }^{1}$, Arham Yakub ${ }^{1}$, Arief Kurnia Riarmanto ${ }^{1}$, Maya Pertiwi ${ }^{1}$, \\ Herman Hidayat ${ }^{1}$, Agung Sih Kurnianto ${ }^{2}$ \\ ${ }^{1}$ Post Graduate Program, Brawijaya University, Malang 65145, Indonesia \\ ${ }^{2}$ Ecology and Animal Diversity Laboratory, Brawijaya University, Malang 65145, Indonesia
}

Article history:

Submission March 2018

Revised August 2018

Accepted August 2018

*Corresponding author:

E-mail:

ritaparmawati1990@gmail.com

\begin{abstract}
Riparians are undergoing extensive reductions and changes in their natural composition into agricultural and urban area. The relationship between the vegetation distribution pattern and the riparian topography factor has been assumed to typically represent a biome-specific or vegetation-specific constant. This study aim is to analyze the vegetation distribution pattern with topography along Alista river in Dau District, Malang. We surveyed 3 stations that represent a zone of edge gradient between the river and the mainland: levee, mid-flood, and slough. We used the wetland classification (Obligate - OBL; Facultative Wetland-FACW; Facultative Upland (FACU); and Upland (UPL) for each species found from various sources. we observed that facultative upland plants have a broad dominance. Mid-floodplain and slough dominated by typical upland species. Although Levee widely consisted of by upland plants, this area has one distinctive obligate species: Equisetum. The presence of OBL species in the levee and mid-floodplain indicate the area is receiving more frequent floods than other areas.
\end{abstract}

Keywords: Alista, pattern, riparian, vegetation

\section{Introduction}

Riparian areas provide many ecosystem services, such as flood prevention, nutrient cycling, carbon dioxide binding, sediment deposits, timber production, recreation and wildlife habitats [1, 2]. These areas, however, are undergoing extensive reductions and changes in their natural composition into agricultural and urban areas [3], deforestation [4], blockage of flow and industrial activities [1]. Riparian plant species are highly selective in their habitat selection, as they are sensitive to changes in flood frequency and duration [5, 6, 7]. As floods have occurred, overbank deposition causes microtopographic variations along the floodplain, which in frequency will become excessive or deficient, thus affecting the composition of vegetation species $[4,5,8,9]$. The relationship between the vegetation distribution pattern and the riparian topography factor has been assumed to typically represent a biome-specific or vegetationspecific constant [10]. However, most of the re- cent studies largely aimed at understanding the distributed environment variables and their association with various vegetations across specific geographical ranges $[11,12,13]$. This study aim is to analyze the vegetation distribution pattern with topography along Alista river basin, district of Dau, Malang, East Java.

\section{Material and Methods Study area}

Alista River (756'21.34"S / 112³1'51.85" T) is located in Dau District, Malang Regency, East Java Province, Indonesia. Alista River is one of the upstream river from the main river in East Java, Brantas. Brantas River has approximately $320 \mathrm{~km}$ long and has an area of $11,800 \mathrm{~km} 2$ or $1 / 4$ of the province of East Java. The river flows from its water springs in Batu towards Kediri in the south and turns into Porong in the north, then empties into the Java Sea. Alista River itself as a river upstream has a variety of reliefs. Located in tropi- 
cal rainforest climate zones, the average temperature fluctuation is about $15.6^{\circ} \mathrm{C}$. The green area covers about $60 \%$ of the area. The river is surrounded by intercropping agricultural areas, open farming, conifer forests, hardwood forests, bamboo and economic forests. The Alista River has 3 sub-basins: Gunung Butak gauge and sub-basin (I), Alista Sub-basin (II), dan Brantas sub-basin (III).

\section{Data sampling}

We surveyed 3 stations in this study to observe Alista river vegetation. Each station represents a zone of edge gradient between the river and the mainland: levee, mid-flood, and slough. To analyze the vegetation, we used a quadrant method that included $100 \mathrm{~m}^{2}=1 \times 1$ for lower vegetation or seedling, $5 \times 5$ for a sapling, and $15 \times 15$ for tree coverage.

Although the floodplain area is approximately 10 - 20 meters wide, depending on its location, we found that this feature also belongs to the slough and levee zones. Apparently, the vegetation community characters observed along the zones will reflect the overall floodplain character.

All trees were measured on each plot. Trees were classified as single perennial stems with a diameter at breast height (DBH) greater than $20 \mathrm{~cm}$ and are recorded by species. Poles were classified as multi-trunked wooden perennial plants and also all single-trunked perennial vegetation with $\mathrm{DBH}$ less than $20 \mathrm{~cm}$. The frequency and dominance of the stake were surveyed using the method of an intercept line along the diagonal line of the plot. Percentage of coverage of each species was calculated by dividing the total linear distance of each species (individual measurements are taken from the nearest $0.5 \mathrm{~cm}$ ) by the total linear distance measured (14-meter diagonal line). Overlapping canopies of different species were recorded based on the distance of each species undergoing intersect. The total canopy distance without stake was also recorded. The composition of herbaceous vegetation (seedling) was surveyed using line intercept method. We marked each 1-meter using wood stick until 14 meters. All herbaceous vegetation, vascular plants, hardwood tree seedlings within the range of the stick were recorded and the number of individuals per plot was measured. Any unobserved herb species on the intersect line were recorded on the datasheet. The presence of wet- land classification groups between different topographic plots were analyzed using frequency and dominance. Dominance was measured as a basal area in $\mathrm{m}^{2} / \mathrm{ha}$ for trees, while percentage of coverage for herbaceous species.

Key riparian vegetation indicators included age class distribution (using diameter class distribution as proxy age). We used the wetland classification (Obligate - OBL; Facultative WetlandFACW; Facultative Upland (FACU); and Upland (UPL) for each species found from various sources $[14,15]$.

We determine which trees are regenerated through an understanding of the demographic shifts among the group of tree species with the age class through diameter as representatives. The facts that tree regeneration is evaluated based on class-size distributions within the survey plot, assuming that the indicator group with smaller diameter specimens may be reduced through the survival of seedling vegetation. If the presence of wetland-dependent species was reduced, we estimated more upland species in the younger age class within the floodplain. The stake or seedling found in the herbaceous survey was understood by estimating the diameter of $1 \mathrm{~cm}$ and belonging to the diameter of the class-size distribution. A note where regeneration was commonly lowered in forests with high canopy cover, but the assumption by which FAC regeneration occurs and FACU relative to OBL and FACW may indicate that the forest is undergoing a transition.

\section{Results and Discussion}

In general, we observed that facultative upland plants have a broad dominance over the limits of seedling vegetation (Figure 1). However, the dominance of the species that we found has decreased further in the next higher vegetation levels. Upland trees dominated the watershed region. Upland tree species which have extensive canopy coverage caused other types of vegetation could not grow properly. We have no found a typical wetland tree existed in the three observed watershed types as well as sampling classification unless upland vegetation.

Type of typical wetland plants that we found was in the seedling classification. However, its dominance was very small compared to upland facultative plants and even the true upland. Some of them were indicated to be the kind of product- 


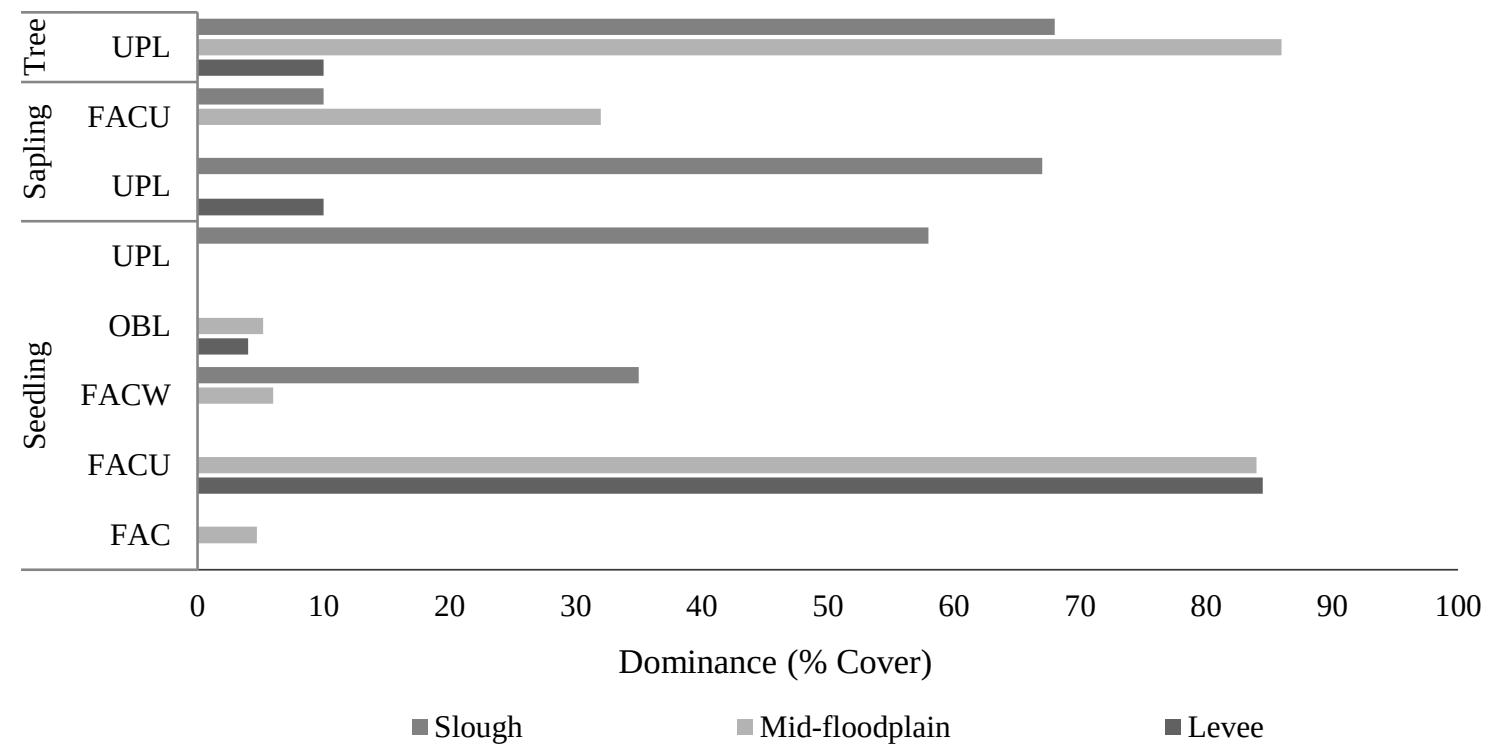

Figure 1. The dominance in five wetland indicator classification : UPL (Upland), OBL (Obligate), FACW (Facultative Wetland), FACU (Facultative Upland), FAC (Facultative) among all sites grouped by topographic zone : slough (grey), mid-floodplain (white), and Levee (black).

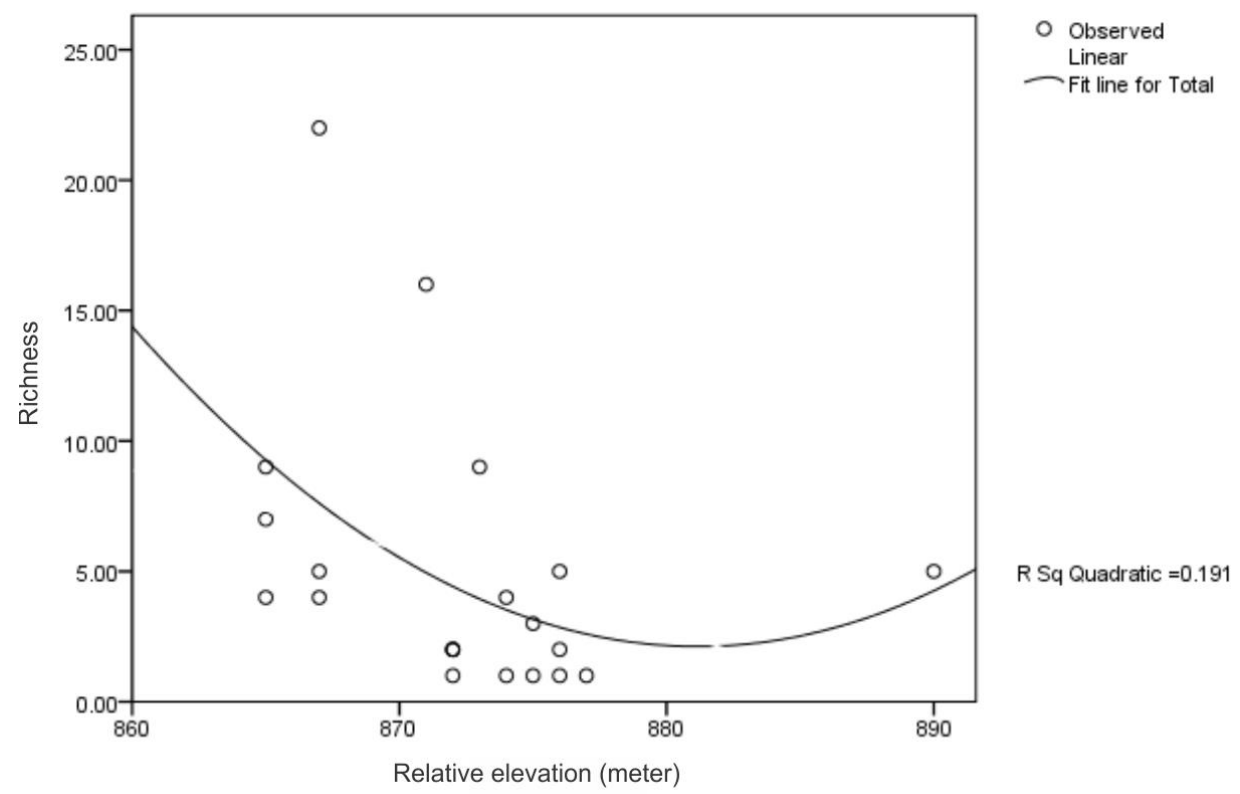

Figure 2. The relationship between tree species richness and relative elevation of plots in all sites

ion crops developed by humans as the opening of the watershed area as agricultural land.

Slough into wet plains that actually have many types of upland plants. This uniqueness seems to be cultivated intentionally by farmers. Production plants such as chili (Capsicum annum) were planted very tightly by blocking the edges of the fields and raising farmland. The slough area is a true wetland representation. It may be very risky if this area be converted into production land.
Mid-floodplain also experienced a lot of typical upland planting. Production trees such as Pinus merkusii are also widely present on this plain. Cultivation of hardwood crops or production in the wetland region is very detrimental in ecological and economic sides. The opening of production land will remove the original wetland flora that can be bioremediatory and become the living place of many fauna [16]. Shade production trees will block precious rays for the life of wetland plants, 
reduce natural water oxidation, and reduce the diversity of valuable insect species. On the other hand, high levels of water actually reduced the production of pine resin and caused various diseases, such as rotting at the root and death [17].

Although Levee widely consisted of by upland plants, this area has one distinctive type of wetland: Equisetum. Some water shelves that are spared from the current are able to accommodate the necessities of life for Equisetum. The top of the cliff is dry and to avoid the flood. Several types of hardwood trees: mahogany and wild crop classification seedlings can live.

The largest density range is in the range 870880 masl (Figure 6). In general, we observed a shift in the composition of plant species as the observed floodplain height was observed. In fact, upland species is more common than wetland in riparian parts of the Alista River. The shifting of riparian functions resulted in minimal vegetation observed in this study (Table 1), as well as loss of typical wetland crops.

Like the other area in Batu, Alista River undergoes a fundamental change in some hydrological structure and its governance due to agriculture and other activities [18]. Serious impacts are faced by abiotic environments, such as flooding, landslides of river cliffs, severe erosion, and rapidly changing soil fertility. The use of river water for consumption is also threatened by the reduction of phytoremediation process against surfactant and heavy metal pollutants by typical wetland plants $[19,20]$.

Research conducted by Garssen et al. (2017) found some species composition that could change the time and intensity of floods [21]. Some of these include hardwood forests that greatly affect many physical factors, such as the timing and intensity of floods, the availability of light, temperature, humidity, and impact on the sustainability of an intact forest and upstream river [21]. Facts about flood tolerance were obtained by conducting an in-depth study of how tree species, shrubs, and herbs are distributed among three topographic zones: Sloughs, mid-floodplains, and levees. We found that floodplain vegetation is sensitive to extreme elevation changes, which will directly affect flood characteristics.

We found OBL species in the levee and midfloodplain zones, which indicate the area is receiving more frequent floods than other areas. Floods cause stress that cannot be tolerated by typical upland plants. However, the frequency of soil due to human disturbance may favor non-wetland species and result in very high competition, especially for light needs [22, 23]. The facts we found showed that the narrow distance at the height of edge zone observed between the sloughs and the mid-floodplain, $75-184 \mathrm{~cm}$, varied at several sites. This suggests that frequent flood frequencies will replace FAC and FACU species, with OBL growing better when flooding [24]. Flood stress also results in reduced plant diversity. The lack of plant diversity in the levee zone has been documented by other studies, as few tree species can be adapted to areas with more frequency inundation and soil anoxia [7, 25].

Future research should focus more on mapping the inundation and vegetation response to flow. Inundation mapping, as indicated by Benke [26], will reveal areas that are flooded on certain parts of the river, which will be directly related to the height difference and riparian vegetation composition. Vegetation response to the flow will predict the changes in environmental conditions.

\section{Conclusion}

Agriculture has affected most types of riparian plants. Upland vegetation dominates on all topography. Slaves that are quite safe from floods are planted by perennials plants: chili. Levee has planted upland plants, but still characterizes the wetland area with the emergence of obligate plants. Mid-floodplain is the most flood-prone area, which is characterized by the survival of a small number of obligate.

\section{Acknowledgment}

Authors thank to the Batu City government staffs for research permission. We also thank to for Fitra A.D. Nugroho for his review on this manuscript.

\section{References}

1. Klapproth JC, Johnson JE (2009) Understanding the science behind riparian forest buffers: Effects on water quality. Blacksburg, VCE Publications.

2. Swanson S, Wyman S, Evans C (2015) Practical grazing management to maintain or restore riparian functions and values on Rangelands. Journal of Rangeland Applications 2: 1 - 28.

3. Simmons ME, Wu XB, Whisenant SG (2007) Bottomland hard wood forest species responses to flooding regimes along an ur- 
banization gradient. Ecological Engineering 29 (3): 223 - 231 doi: 10.1016/j.ecoleng.2006.07.005.

4. Osterkamp WR, Hupp CR (2010) Fluvial processes and vegetation - Glimpses of the past, the present, and perhabs the future. Geomorphology 116 (3): 274 - 285. doi:10.1016/j.geomorph. 2009.11.018

5. Battaglia LL, Sharitz RR (2006) Responses of floodplain forest species to spatially condensed gradients: A test of the floodshade tolerance tradeoff hypothesis. Oecologia 147 (1): 108 118. doi: 10.1007/s00442-005-0245-7.

6. Glaeser J, Wulf M (2009) Effects of water regime and habitat continuity on the plant species composition of floodplain forests. Journal of Vegetation Science 20 (1): $37-48$ doi:10.1111/j.1654-1103.2009.0528.x

7. Kupfer JA, Meitzen KM, Pipkin AR (2010) Hydrogeomorphic controls of early post-logging successional pathways in a southern floodplain forest. Forest Ecology and Management 259 (10): 1880 - 1889. doi:10.1016/j/foreco.2010.01.050.

8. Almquist BE, Jack SB, Messina MG (2002) Variation of the treefall gap regime in a bottomland hardwood forest: Relationships with microtopography. Forest Ecology and Management 157 (1): 155 - 163. doi:10.1016/S0378-1127(00)00646-0

9. Naiman RJ, Decamps H, McClain ME (2005) Riparia: Ecology, conservation and management of streamside communities. Burlington, Elsevier Academic Press.

10. Chang CT, Lin TC, Wang SF (2011) Assessing growing season beginning and end dates and their relation to climate in Taiwan using satellite data. International Journal of Remote Sensing 32 (18): 5035 - 5058. doi: 10.1080/01431161.2010.494635.

11. Nelson A, Oberthür T, Cook S (2007) Multi-scale correlations between topography and vegetation in a hillside catchment of Honduras. International Journal of Geographical Information Science 21 (2): 145 - 174. doi:10.1080/1365881060085226.

12. Propastin P (2011) Multiscale analysis of the relationship between topography and aboveground biomass in the tropical rainforests of Sulawesi, Indonesia. International Journal of Geographical Information Science 25 (3): 455 - 472 doi:10.1080/13658816.2010.518570

13. Gao Y, Huang J, Li S, Li S (2012) Spatial pattern of non-stationarity and scale-dependent relationships between NDVI and climatic factors: A case study in Qinghai-Tibet Plateau, China. Ecological Indicators 20 (2012): $170 \quad-176$ doi:10.1016/j.ecolind.2012.02.007.

14. U.S. Dept of Agriculture-Natural Resources Conservation Service (USDA-NRCS) (2010) The PLANTS Database. http://plants.usda.gov. Accessed date: 22 February 2010.

15. Azliza M, Nazre M, Mohamad-Roslan MK, Shamsul K (2012) Characterization of riparian plant community in lowland forest of Peninsular Malaysia. International Journal of Botany 8 (4): 181 - 191. doi: 10.3293/ijb.2012.181.191.

16. Patten DT (2006) Restoration of wetland and riparian systems: The role of science, adaptive management, history, and values. Journal of Contemporary Water Research and Education 134 (1): 9 - 18. doi: 10.1111/j.1936-704X.2006.mp134001003.x.

17. Striker GG (2012) Flooding stress on plants: anatomical, morphological, and physiological responses, John Mworia (Ed). http://www.intechopen.com/books/botany/flooding-stress-onplants-anatomical-morphological-andphysiological-responses. Accessed date: 16 March 2018.

18. Widianto SD, Sudarto, Lestariningsih ID (2010) Implementasi Kaji Cepat Hidrologi (RHA) di hulu DAS Brantas, Jawa Timur. Working Paper n. 121. Bogor, Indonesia. doi: 10.5716/WP103 38.PDF.

19. Ramprasad C, Philip L (2015) Surfactants and personal care products removal in pilot scale horizontal and vertical flow constructed wetlands while treating greywater. Chemical Engineering Journal 284 (2016): 458 - 468. doi: 10.1016.j.cej.2015.08.092.

20. Sukumuran D (2013) Phytoremediation of heavy metals from industrial effluent using constructed wetland technology. Applied Ecology and Environmental Sciences 1 (5): 92 - 97. doi:10.12691/aees-1-5-4.

21. Garssen AG, Baattrup-Pedersen A, Riis T (2016) Effects of increased flooding on riparian vegetation: Field experiments simulating climate change along five European lowland streams. Global Change Biology 23 (8): 3052 - 3063. doi: 10.1111/gcb.13687.

22. Craine JM, Dybzinski R (2013) Mechanisms of Plant competition for nutrients and light. Functional Ecology 27 (4): 833 840. doi: 10.1111/1365-2435.12081.

23. Dewey JC, Schoenholtz SH, Shepard JP, Messina MG (2006) Issues related to wetland delineation of a Texas, USA bottomland hardwood forest. Wetlands 26 (2): 410 - 429. doi: 10.1672/0277-5212(2006)26[410:IRTWDO]2.0.CO;2.

24. Vervuren PJA, Blom CWPM, De Kroon H (2003) Extreme flooding events on the Rhine and the survival and distribution of riparian plant species. Journal of Ecology 91 (1): 135 - 146. doi:10.1046/j.1365-2745.2003.00749.x.

25. Franklin SB, Kupfer JA, Pezeshki SR et al. (2009) Complex effects of channelization and levee construction on western tennesse floodplain forest function. Wetlands 29(2): 451 - 464. doi: 10.1672/08-59.1.

26. Benke AC, Chaubey I, Ward GM, Dunn EL (2000) Flood pulse dynamics of an unregulated river floodplain in the Southeastern U.S. Coastal Plain. Ecology 81 (10): 2730-2741. doi: 10.1890/0012-9658(2000)081[2730:FPDOAU]2.0.CO;2. 
This page is intentionally left blank. 